\title{
Enforcement of International Humanitarian Law
}

Gentian Zyberi

Norwegian Centre for Human Rights, University of Oslo, Oslo, Norway

\begin{abstract}
This chapter provides a critical assessment of the enforcement system of international humanitarian law (IHL), also referred to as the law of armed conflict (LOAC) or jus in bello. The notion of enforcement should be distinguished from that of implementation, which is much broader, in that enforcement involves at least some degree of sanctioning for violations of IHL, which could encompass individual criminal responsibility or State responsibility and liability for reparations. After briefly discussing several factors that induce compliance with IHL, this chapter focuses on IHL enforcement at the three possible levels. At the domestic level, the chapter starts from the obligations imposed on States under the 1949 Geneva Conventions (GCs) and their two Additional Protocols of 1977 (AP1 and AP2), including the obligation to investigate and prosecute war crimes amounting to grave breaches. At the regional level, the chapter addresses the enforcement of IHL through the regional human rights systems, focusing on the three regional human rights courts, but also including relevant findings by the Inter-American Commission on Human Rights and the African Commission on Human and Peoples' Rights. At the international level, the chapter analyzes the enforcement of IHL by discussing briefly the mechanisms included under IHL treaties, including Protecting Powers, the ad hoc and the standing International Fact-Finding Commission (established through Article 90 of AP1), and the ICRC. The focus then shifts onto the main UN organs, including the Security Council, the General Assembly (and its subsidiary bodies, the Human Rights Council and the International Law Commission), and the International Court of Justice (ICJ). Another type of enforcement mechanisms addressed here includes international criminal courts and tribunals. Finally, the chapter addresses briefly the role of non-State actors, focusing on non-State armed groups (NSAGs) and nongovernmental organizations (NGOs).
\end{abstract}

Keywords International humanitarian law - IHL - Law of armed conflict - Jus in bello - Enforcement - United Nations - Geneva Conventions and Additional Protocols - International Committee of the Red Cross

\section{Introduction}

This chapter provides a critical assessment of the enforcement system of international humanitarian law (IHL), also referred to as the law of armed conflict (LOAC) or jus in bello (Kalshoven 2007, p. 593-620; Schmitt and von Heinegg 2012; Schabas 2001, p. 439-459; Green 2003, p. 101-131; Vöneky 2013, p. 647-700; Crawford and Pert 2015, p. 235-266; Melzer 2016, p. 263-308). Enforcement involves a variety of measures aimed at ensuring observance of IHL through international monitoring, to assigning responsibility for serious violations through courts or other mechanisms, to providing reparations for serious IHL violations to affected individuals or States. The UK Manual of the Law of Armed Conflict provides a long list of actions aimed at the effective enforcement of IHL, which includes, among others, disseminating knowledge within the armed 
forces, international legal adjudication, good offices and mediation, media publicity, penal and disciplinary measures, demands for reparations in respect of violations, and reprisals by the aggrieved State (UK Ministry of Defence 2004, p. 412-413). The notion of enforcement should be distinguished from that of implementation, which is much broader, in that enforcement involves at least some degree or type of sanctioning for violations of IHL, which ranges from public condemnation of violations to individual criminal responsibility or State responsibility (Sassòli 2002, p. 401-434) and liability for reparations. Section VI of the 2005 ICRC study on customary IHL is entitled "Implementation" and includes five chapters, namely, Chapter 40 "Compliance with International Humanitarian Law," Chapter 41 "Enforcement of International Humanitarian Law," Chapter 42 "Responsibility and Reparation," Chapter 43 "Individual Responsibility," and Chapter 44 "War Crimes" (Henckaerts and Doswald-Beck 2005). The notion of sanctioning adopted here is quite broad, including also public statements by State officials, by staff of international organizations, or reports by NGOs that address serious IHL violations.

The assessment of the IHL enforcement system involves a two-step approach: first, an introduction of the extant enforcement mechanisms, at the respective levels, namely, the domestic (Blank 2011, p. 205-224; Weill 2014a; ICRC database on national implementation), the regional (de Wet and Kleffner 2014, chapters 13, 14, and 15), and the international level (Schmitt and von Heinegg 2012; Darcy 2014). Second, an analysis of the enforcement efforts of each mechanism is provided, highlighting the main achievements and persisting challenges. This analysis covers the system of enforcement of IHL for both international (IACs) and non-international armed conflicts (NIACs). When considering the enforcement process, it is possible to categorize that in terms of judicial and nonjudicial enforcement; in terms of the law of international responsibility, as responsibility of States, international organizations, individuals, or non-State actors; and, in terms of the levels or layers of enforcement, the domestic, the regional, and the international levels. After briefly discussing several factors that induce compliance with IHL, this chapter focuses on IHL enforcement at each of the three levels.

At the domestic level, the chapter focuses on the obligations imposed on States under the 1949 Geneva Conventions (GCs) and their two Additional Protocols of 1977 (AP1 and AP2), including the obligation to investigate and prosecute war crimes amounting to grave breaches. At the regional level, the analysis focuses on the three regional human rights courts while including relevant findings by the Inter-American and the African Commission on Human Rights. At the international level, the analysis includes the mechanisms established under the main IHL treaties, including Protecting Powers, the ad hoc commissions and the standing International Fact-Finding Commission (established under Article 90 of AP1), and the ICRC. The focus then shifts onto the main UN organs, including the Security Council, the General Assembly (and its two subsidiary bodies, the Human Rights Council and the International Law Commission), and the International Court of Justice (ICJ). A discussion of international enforcement mechanisms would not be complete without analyzing the work of international criminal courts and tribunals. Finally, the chapter addresses briefly the role of non-State armed groups (NSAGs) and nongovernmental organizations (NGOs) in enforcing IHL.

\section{Some Factors Inducing Compliance with IHL}

There are several considerations and factors built into the fabric of IHL, which are aimed at ensuring compliance by warrying parties and others affected. Some of these measures relate to the general implementation of IHL during peacetime, including dissemination of IHL, education and awarenessraising among the general public, adequate training of the military forces, and other national 
implementing measures, aimed at ensuring conditions furthering compliance with IHL. Other measures, directly aimed at the enforcement of IHL during armed conflict, include activities by a range of actors, including those of Protecting Powers, the ICRC, the main UN organs, good offices and related diplomatic activities at the international and the regional level, international fact-finding commissions, penal and disciplinary measures, and activities of NGOs. Besides relevant legal considerations, the personal conviction and sense of moral responsibility of the individuals involved, expressed in the form of the principle of chivalry, are quite important for ensuring compliance with IHL (Gill 2013, p. 33-51). As Gill has noted, chivalry and martial honor have always been part of the "code of the warrior" and have played a significant role in the development of the law of war, notwithstanding undeniable obstacles and challenges to their application (Gill 2013, p. 49). Disregard for this ethical and moral code has become more prevalent in recent armed conflicts between States and NSAGs.

The success of the measures and activities carried out by different actors aimed at ensuring compliance with IHL depends on a range of factors, internal and external, which influence the behavior of the parties to an armed conflict. Several general weaknesses and challenges to the enforcement of IHL have been identified, including a lack of incentives on the part of NSAGs to comply with IHL, use of new technologies, inability or unwillingness on the part of warrying parties to fulfil the needs of civilians and prohibition of access to humanitarian assistance, use of explosive weapons in densely populated areas, tendency of States to label as "terrorist" all acts of warfare committed by NSAGs against them especially in NIACs, and so on (ICRC 2015, p. 1427-1502; Sassòli 2007, p. 45-73). Generating respect for IHL remains a troublesome endeavor, despite continued and sustained efforts by different stakeholders. However, as the following sections will show, major progress has been done in the course of the last 150 years, both in terms of substantive law and in terms of enforcement mechanisms and practices.

\section{Enforcing IHL}

Article 1 common to the 1949 Geneva Conventions provides that States and other parties to an armed conflict have an obligation to "respect and ensure respect for" IHL "in all circumstances." As Melzer has noted, this duty has several aspects, including (1) a negative duty to abstain from any deliberate violation of IHL, (2) a positive internal duty to ensure the national implementation and application of IHL, and (3) a positive external duty of States to exert bilateral or multilateral pressure on other States or belligerent parties to comply with IHL (Melzer 2016, p. 268). These duties are part of the law of international responsibility.

Treaty and customary IHL have codified five types of war crimes, which eventually would trigger international responsibility, for States, individuals, international organizations, as well as for nonState actors more generally (Jørgensen 2003; Bonafè 2009; Crawford et al. 2010; van Sliedregt 2012). These five categories are as follows: war crimes against persons requiring particular protection, war crimes against property and other rights, prohibited methods of warfare (attacks on nonmilitary targets and other prohibited methods), prohibited means of warfare, crimes against humanitarian assistance, and crimes against peacekeeping operations (Nerlich 2009, p. 566-570). This is a topical characterization of war crimes, based on the protection included under both treaty and customary IHL. The typology generally employed by the international criminal courts and tribunals is based on that of armed conflicts, namely, war crimes in IACs and in NIACs. This is the case in the ICTY Statute (Article 2 on "grave breaches of the Geneva Conventions of 1949" and Article 3 on "violations of the laws or customs of war"), the ICTR Statute (Article 4 on "violations of Article 3 Common to the 
Geneva Conventions and of Additional Protocol II"), and in the ICC Statute (Article 8 on "war crimes") (Vité 2009, p. 69-94). Notably, although formally preserving the distinction between war crimes in IACs and NIACs, the case law of these international courts has helped bridge the protection gap between the two types of armed conflict.

The enforcement of IHL happens at three levels, domestic, regional, and international, and involves different types of mechanisms. The chapter devotes significant attention to judicial enforcement, but also other types of mechanisms are included. Despite operating at different levels, the activity of the courts is connected, since in order to bring a case before a regional court it usually is necessary to exhaust available domestic remedies. Similarly, the permanent International Criminal Court (ICC), that has jurisdiction over war crimes, operates on the basis of the principle of complementarity and will investigate a situation and start cases if a State is unable or unwilling to do so by itself through its own domestic courts (ICC Statute, Articles 17 and 19; El Zeidy 2008; Kleffner 2008; Stahn and El Zeidy 2011; Nouwen 2013). The following sections explain and analyze the different mechanisms available at the three levels, highlighting their main achievements and shortcomings.

\section{Enforcement at the Domestic Level}

The domestic mechanisms provide the first level of enforcement of IHL. As mentioned above, Article 1 common to the Geneva Conventions imposes an obligation on States to respect and ensure respect for IHL. This has been confirmed by the International Court of Justice as applicable to both international and non-international armed conflicts (ICJ, Nicaragua 1986, paras. 115, 216, 255, and 256; ICJ, Legal Consequences of the Construction of a Wall in the Occupied Palestinian Territory 2004, paras. 158-9). Moreover, the ICJ has found that "a great many rules of humanitarian law applicable in armed conflict are so fundamental to the respect of the human person and elementary considerations of humanity ... that they are to be observed by all States whether or not they have ratified the conventions that contain them, because they constitute intransgressible principles of international customary law" (ICJ, Legality of the Threat or Use of Nuclear Weapons 1996, para. 79). While there is more clarity about a State's own obligation to respect IHL (ICRC Commentary to Geneva Convention IV, p. 15-17; Boisson de Chazournes and Condorelli 2000, p. 67-87; Focarelli 2010, p. 125-171; Dörmann and Serralvo 2014, p. 707-736; ICJ, Legal Consequences of the Construction of a Wall in the Occupied Palestinian Territory 2004, paras. 149-153), what a State can and should do to ensure respect for IHL by another State or non-State actors remains debatable. Besides calling on other States to stay within the confines of IHL, publicly condemning violations, and recalling diplomatic staff or severing diplomatic relations, States must ensure they do not become complicit in committing war crimes by supplying weapons used to commit war crimes (Arms Trade Treaty, Article 6(3)). This last issue has been raised in recent armed conflicts, such as that in Syria and Yemen.

Given that IHL rules incorporate obligations which are essentially of an erga omnes character (ICJ, Legal Consequences of the Construction of a Wall in the Occupied Palestinian Territory 2004, para. 157) under Article 48 of the International Law Commission's (ILC) Articles on State Responsibility, a State other than an injured State can ask cessation of the internationally wrongful act and assurances and guarantees of non-repetition and performance of the obligation of reparation, in the interest of the injured State or of the beneficiaries of the obligation breached. More generally, from the perspective of the law on international responsibility, a State must not recognize an illegal situation or render aid or assistance in its maintenance. 
Given that the international legal system is State-centered, States play a primary role in the enforcement of IHL. As Melzer has noted, the duty to respect and ensure respect may involve a broad range of preventive, supervisory, and punitive measures, including (a) domestic legislation and regulations; (b) instructions, military orders, and legal advice; (c) training and the dissemination of all pertinent information; (d) the establishment of national IHL committees; (e) technical preparation; and (f) criminal repression (Melzer 2016, p. 268-269). The universally ratified 1949 Geneva Conventions, as well as the 1977 Additional Protocol I, impose on States an obligation to incorporate IHL into domestic law, especially with regard to penalizing conduct which has been described as grave breaches of the Geneva Conventions (GC1, Article 49; GC2, Article 50; GC3, Article 129; and GC4, Article 146; AP1, Article 85(1)). Some of the main war crimes falling under the grave breaches system include willful killing, torture or inhuman treatment, biological experiments, willfully causing great suffering, causing serious injury to body or heath, unlawful and wanton extensive destruction, and appropriation of property not justified by military necessity. Other protections under IHL that need to be included into domestic legislation include those relating to the protection of the Red Cross emblem, the protection of cultural property, and the prohibition of certain weapons. The obligation to criminalize war crimes is further strengthened through the statutes of the two ad hoc international criminal tribunals for the former Yugoslavia and Rwanda (ICTY and ICTR) and that of the permanent ICC.

National courts play an essential role in enforcing IHL (Weill 2014b, p. 859-879; International Crimes Database, T.M.C. Asser Institute). The national military codes and the military justice system, as well as the military chain of command, play an equally important role. In dealing with the structural aspects of ensuring enforcement of IHL by national courts, Weill has pointed out that these include the existence of domestic legislation that allows for (1) the independence and impartiality of the judiciary, (2) the application and enforcement of IHL rules by national judges (either through a direct application of IHL rules into the national legal system or through their endorsement through national laws), (3) access to courts in cases of IHL violations, and (4) the equal and effective application of the law by the judiciary (Weill 2014b, p. 860). A problematic development has been the effort of US authorities to exclude from the protection of the law the so-called unlawful combatants, by detaining them in the Guantanamo Bay military base or through the extraordinary renditions program (ECtHR, El-Masri v. "The former Yugoslav Republic of Macedonia" 2012a; Al Nashiri v. Poland 2014a; and Husayn (Abu Zubaydah) v. Poland 2014b). The US Supreme Court has countered this effort in several of its decisions (US Supreme Court, Hamdan v. Rumsfeld 2006; Boumediene v. Bush 2008). However, serious challenges remain with regard to access to courts and the equal and effective application of the law in many countries.

The criminal prosecution of serious IHL violations can occur through courts martial or domestic courts, depending on the choice of the domestic legislator. Several armies have their own justice system that deals with military offences, including war crimes. The 1949 Geneva Conventions have created a system of universal jurisdiction (GC1, Article 49; GC2, Article 50; GC3, Article 129; GC4, Article 146), whereby every State has an obligation to search for persons alleged to have committed, or to have ordered to be committed, such grave breaches and bring such persons, regardless of their nationality, before its own courts. A State may also, if it prefers, and in accordance with the provisions of its own legislation, hand such persons over for trial to another High Contracting Party concerned, provided such High Contracting Party has made out a "prima facie" case.

The universal jurisdiction concerning violations amounting to grave breaches is accompanied by the principle of extradite or prosecute ( aut dedere aut judicare) (Final Report of the International Law Commission 2014). Although included in the 1949 Geneva Conventions, and incorporated in the domestic jurisdiction of States parties to these treaties, applying the principle of universal jurisdiction 
is not without problems, because of limitations imposed by diplomatic immunity and other problems of a more practical nature. There have been several high profile cases brought before domestic courts on charges of war crimes where the issue of immunity has been invoked (ICJ, Arrest Warrant 2002, paras. 56-61, at 58; Inazumi 2005; Macedo 2006; van Alebeek 2008; Seibert-Fohr 2009; Orakhelashvili 2015; Kwakwa 2004, p. 407-430; Princeton Project on Universal Jurisdiction 2001). The International Law Commission is currently working on this topic. It seems unlikely that domestic courts will be granted jurisdiction to try incumbent senior foreign State officials that enjoy immunity under international law.

\section{Enforcement at the Regional Level}

The enforcement of IHL at the regional level happens through different mechanisms of a judicial or nonjudicial nature. Some of the main regional organizations include the Organization of American States (OAS), the Council of Europe (CoE), the European Union (EU), the African Union (AU), and the Organization for Security and Co-operation in Europe (OSCE). Ensuring respect for human rights in armed conflict is part of the mandate of these regional organizations. Given the close relationship between human rights and humanitarian law (Oberleitner 2015) and the resurgence of armed conflicts in different parts of the world, the activity of regional organizations has increasingly addressed situations of armed conflict. Although regional human rights courts are not properly equipped to deal with mass atrocity crimes, including war crimes, their case law is important for the enforcement of IHL, especially in terms of clarifying State obligations in situations of armed conflicts at home and armed forces operating abroad. This section focuses on enforcement of IHL through the three regional human rights courts, the European, the Inter-American, and the African, while also taking into account relevant work of the Inter-American and the African human rights' commissions.

\section{The European Court of Human Rights}

The ECtHR plays a significant role in the enforcement of IHL, despite the fact that IHL violations as such do not fall into the scope of the European Convention on Human Rights (ECHR) (Gioia 2011, p. 201-249; Oellers-Frahm 2014, p. 333-364; Hartridge 2014, p. 257-287). The enforcement of IHL through the case law of the ECtHR involves both individual applications under Article 34, as well as inter-State cases under Article 33. Some of the inter-State cases relating to armed conflict are Cyprus v. Turkey, Georgia v. Russian Federation, and Ukraine v. Russian Federation. Individual applications have covered violations related to the conflict between Turkish security forces and the PKK (Workers' Party of Kurdistan), the Armenian-Azerbaijani conflict over Nagorno-Karabakh, the war in Croatia and in Bosnia and Herzegovina, the 1999 NATO operation in the former Yugoslavia, and the conflict in Chechnya. There have been also a number of cases relating to the activity of European States' military forces abroad, including cases concerning the ISAF operation in Afghanistan and the international military operations in Iraq. Most of the violations relate to the right to life (Article 2) (ECtHR, McCann and Others v. the United Kingdom 1995), the prohibition of torture and inhuman or degrading treatment (Article 3) (ECtHR, Aksoy v. Turkey 1996; Öcalan v. Turkey 2005), the right to liberty and security (Article 5) (ECtHR, A. and Others v. the United Kingdom 2009), and the right to a fair trial (Article 6) (ECtHR, Cyprus v. Turkey 2001; Marguš v. Croatia 2012b; Stichting Mothers of Srebrenica and Others v. the Netherlands 2013). However, several cases also relate to respect for the home and property of displaced persons and violation of the right to an effective remedy (Article 13). 
The cases that consider the right to life and the freedom from arbitrary detention demonstrate the difficulty that the Court is faced with when dealing with situations of armed conflict (Hartridge 2014, p. 285). The ECtHR has been reluctant to engage with IHL, unless the State concerned has declared martial law or a state of emergency. So far, nine States have had recourse to this right, namely, Albania, Armenia, France, Georgia, Greece, Ireland, Turkey, the United Kingdom, and Ukraine. Article 15(2) lists as non-derogable the right to life (Article 2), except in respect of deaths resulting from lawful acts of war, the prohibition of torture and inhuman or degrading treatment or punishment (Article 3), the prohibition of slavery and servitude (Article 4), and no punishment without law (Article 7). The notice of derogation under Article 15(3) of the ECHR amounts to the consent of the State concerned to accept the special or extended power of the Court to apply not only the law enshrined in the ECHR but also IHL (Oellers-Frahm 2014, p. 342). Oellers-Frahm has noted that particularly in cases concerning the right to life the ECtHR, although applying Article 2 of the ECHR, has used the vocabulary of humanitarian law such as "incidental loss of civilian life," "choice of means and methods," "legitimate military targets," and "disproportionality in the weapons used" and resorted to the cardinal principles of IHL, namely, limitations of means and methods of combat, the principle of distinction, and the principle of proportionality (Oellers-Frahm 2014, p. 350). Some of the shortcomings identified are the reluctance to apply and the inconsistent application of IHL, ECtHR's jurisdictional limitation to cases where rights are violated by a State, and the issue of immunity of international organizations. That said, overall, the case law of the ECtHR has helped clarify certain substantive and procedural aspects of State obligations under the ECHR in situations of armed conflict.

\section{The Inter-American Court and Commission on Human Rights}

The Inter-American system of human rights protection is quite comprehensive in terms of substantive human rights, as well as the mechanisms it includes for their enforcement, including both the Commission and the Court (IACtHR and IACmHR, or just Court and Commission). As Shelton has noted, this system has become a forum for the enforcement of IHL due to the number of cases presented and reports prepared that concern States in which internal armed conflicts exist (Shelton 2014, p. 392). Similar to Article 15 of the ECHR, Article 27 of the Inter-American Convention on Human Rights (IACHR) allows for derogations in time of war, public danger, or other emergency that threatens the independence or security of a State party. Article 27(2) provides a list of non-derogable rights, including the right to juridical personality (Article 3), the right to life (Article 4), the right to humane treatment (Article 5), and freedom from slavery (Article 6). The Court has found that "essential" judicial guarantees which are not subject to derogation, according to Article 27(2) of the Convention, include habeas corpus (Art. 7(6)), amparo, and any other effective remedy before judges or competent tribunals (Art. 25(1)), which is designed to guarantee the respect of the rights and freedoms whose suspension is not authorized by the Convention (Judicial Guarantees in States of Emergency (Arts. 27(2), 25, and 8 American Convention on Human Rights) 1987b, para. 41(1); Habeas Corpus in Emergency Situations (Arts. 27(2), 25(1), and 7(6) American Convention on Human Rights $\underline{1987 a}$ ). The Commission has a broader scope of jurisdiction that covers all OAS States and a dual function which includes a monitoring function, besides accepting individual complaints. Some of the main cases the Commission has dealt with include serious human rights violations (massacres committed by the military juntas), specific issues as terrorism and human rights, and the closure of the notorious Guantanamo prison. The Commission and the Court appear to have wavered 
at times in their views about the direct applicability of IHL, although they are in agreement that alleged violations of the Declaration or Convention must be assessed during armed conflicts in the light of IHL norms as lex specialis (Shelton 2014, p. 377). Nevertheless, both mechanisms have provided an important contribution to IHL enforcement, through the emphasis placed on the right to truth, the protection of the civilian population, and reparations for war crimes (Bámaca-Velásquez $\mathrm{V}$ Guatemala 2000; Case of the Pueblo Bello Massacre v Colombia 2006; Buis 2008, p. 269-293; Cerna 2011, p. 3-52; Shelton 2014, p. 365-394; Tabak 2016, p. 661-715). Shelton has noted that the use of IHL experts in presenting the cases could benefit the tribunals in achieving this goal, since more commissioners and judges are not specialists in IHL (Shelton 2014, p. 392). Heeding this specific concern, also valid for proceedings before the other regional courts, would help the Inter-American Court and the Commission avoid fragmentation or contradictory findings, as well as potentially increase the acceptability of their decisions by the States concerned.

\section{The African Court and Commission on Human and Peoples' Rights}

The two-tiered African system of human rights protection with the Commission and the Court (ACmHPR and ACtHPR) is potentially very important for the enforcement of IHL in the African continent. Despite the currently limited case law, the ongoing consolidation of the African regional human rights system and the existence of several NIACs means that both the Commission and the Court will be increasingly involved in cases and situations where IHL is applicable (ACmHPR, Commission Nationale des Droits de l'Homme et des Libertés v Chad 2000 (Chad Mass Violations case); Amnesty International and Others v Sudan 2007a; Democratic Republic of Congo v Burundi, Rwanda and Uganda 2003; Article 19 v Eritrea 2007b; Viljoen 2014, p. 303-332; Krieger 2015). Interestingly, the African Charter on Human and Peoples Rights (ACHPR or African Charter) does not contain a clause allowing for derogations, and the African Commission has held that derogations are not allowed (ACmHPR, Commission Nationale des Droits de l'Homme et des Libertés v Chad $\underline{2000}$, para 21). While the African Charter entitles the African Commission to make findings of massive and serious violations of human rights, under Article 58(1) the Commission is only competent to "draw the attention" of the AU Assembly of Heads of State and Government to the existence of these violations and must await a request by the Assembly mandating it to undertake "an in-depth study" and report back to the Assembly (Viljoen 2014, p. 311-312). As Viljoen has noted, despite a number of such referrals by the Commission, the Assembly has never authorized an in-depth study under Article 58, which to some extent explains the Commission's apparent reluctance to explicitly find "massive or serious violations" of Charter provisions (Viljoen 2014, p. 312). Violations of IHL may be raised before the Commission or the Court. At the Commission such issues may be raised through individual cases, as well as part of the State reporting process, either by the State in the report itself or by the African Commission in its Concluding Observations on the report (Viljoen 2014, p. 320). The Commission has dealt with several serious IHL violations, including rape, dumping of bodies and mass burials, forced displacement, destruction of property, and extrajudicial executions (ACmHPR, Sudan Human Rights Organisation \& Centre on Housing Rights and Evictions (COHRE) v Sudan 2009). The subject-matter jurisdiction of the Commission can be expanded through Articles 60 and 61 of the African Charter. Under Article 60, the Commission can refer to treaties adopted under the African Union framework, which make specific references to IHL, such as the 2003 Protocol to the African Charter on the Rights of Women in Africa (Women's Protocol) and 
the 2009 AU Convention for the Protection and Assistance of Internally Displaced Persons in Africa (IDP Convention) (Viljoen 2014, p. 321-322). Additionally, by finding that the six main humanitarian law treaties fall within the scope of Article 61 of the African Charter, the Commission can use relevant IHL provisions in the determination of the case at hand (Viljoen 2014, p. 315). However, the Commission has not been consistent in taking this approach and making use of IHL treaty provisions or rules of customary IHL.

The ACtHPR has been vested with broad jurisdiction under Article 3(1), which extends to all cases and disputes submitted to it concerning the interpretation and application of the African Charter, the Protocol, and any other relevant human rights instrument ratified by the States concerned. Both the contentious and the advisory function of the Court are relevant. In a case relating to the armed conflict in Libya, the Court acting proprio motu ordered the Libyan government to refrain from any action that would result in loss of life or violation of physical integrity of persons, which could be a breach of the provisions of the Charter or of other human rights instruments to which Libya is a party (ACtHPR, African Commission on Human and Peoples' Rights v. Great Socialist People's Libyan Arab Jamahiriya 2011, para. 25(1); case discontinued in March 2013). Given the dearth of cases, it remains to be seen to what extent parties to proceedings before the Court will rely on IHL. The advisory jurisdiction of the Court might be quite important in terms of clarifying the relationship between human rights and humanitarian law within the African system of human rights protection, as well as concerning specific issues that have arisen in the context of armed conflicts in African countries. The established practice of the Inter-American and the European human rights mechanisms could eventually assist the African human rights organs when dealing with similar issues.

\section{Enforcement at the International Level}

The international level of enforcement of IHL is quite complex, in that it includes a variety of mechanisms of a political, judicial, fact-finding, and good offices nature, which are aimed at ensuring better enforcement of IHL by warrying parties in both IACs and NIACs. This section will cover first the traditional enforcement mechanisms included under IHL treaties themselves. Then, the focus shall turn on the enforcement through the UN system, starting with the UN main organs, namely, the Security Council, the General Assembly, and the International Court of Justice. The activity of the International Law Commission and the Human Rights Council is briefly discussed, in the context of the work of the General Assembly. Finally, the subsequent section will analyze IHL enforcement through international criminal courts and tribunals.

\section{Enforcement Mechanisms Included in IHL Treaties}

International humanitarian law treaties have established four mechanisms for the enforcement of IHL, namely, the Protecting Powers (GCs 1-3, Common Article 8; GC4, Article 9; and AP1, Article 5), the ICRC, the ad hoc fact-finding commissions under the GCs (GC1, Article 52; GC2, Article 53; GC3, Article 132; and GC4, Article 149), and a standing International Fact-finding Commission (AP1, Article 90). The Protecting Powers system has been used only five times (Crawford and Pert 2015, p. 240), the ad hoc fact-finding commissions have never been used (Crawford and Pert 2015, p. 243), and the standing International Fact-Finding Commission has only been used once so far (OSCE request in 2017). This situation provides a very bleak picture of the practical relevance of these three potentially important IHL treaty-based mechanisms. 
Protecting Powers have a number of responsibilities for enforcing IHL, including visiting protected persons in detention and providing assistance in judicial proceedings against protected persons. The reasons behind the limited use of Protecting Powers are related to the substantive duties such a position entails, the need for agreement on such appointments by the warring parties, and political motives, including reluctance of States to submit to supervision by a third State during an armed conflict (Pfanner 2009, 287). Given the prominent role played by the ICRC in covering similar functions, it is unlikely that the mechanism of Protecting Powers will be used with increased frequency than it has been the case so far.

The four Geneva Conventions allow for the establishment of ad hoc fact-finding commissions. The relevant provisions state that, "[a]t the request of a Party to the conflict, an enquiry shall be instituted, in a manner to be decided between the interested Parties, concerning any alleged violation of the Convention" (GC1, Article 52; GC2, Article 53; GC3, Article 132; and GC4, Article 149). Given that initiating this enquiry procedure depends on the consent of the warring parties, it is unlikely that the mechanism will ever be used. Given the lack of requests for making use of this ad hoc procedure, the international community decided to establish a standing International Fact-Finding Commission (IFFC). Under Article 90(2)(c) of AP1, the IFFC is competent to (i) enquire into any facts alleged to be a grave breach as defined in the Conventions and this Protocol or other serious violation of the Conventions or of this Protocol and (ii) facilitate, through its good offices, the restoration of an attitude of respect for the Conventions and this Protocol.

While potentially quite important, the fact that since its establishment in 1991 this mechanism has only been used once shows that States are reluctant to accept the IFFC's authority or consent to its investigation of serious violations of IHL. However, the first use of this mechanism to investigate an explosion involving personnel and a vehicle of the OSCE's Special Monitoring Mission (SMM) in Eastern Ukraine shows that the Commission can be used effectively to enquire into situations potentially involving IHL violations (Azzarello and Niederhauser 2018).

The ICRC's role in enforcing IHL is manifold, embedded in the IHL treaties, and further developed through its institutional practice over time. This institution is enjoined "to undertake the tasks incumbent upon it under the Geneva Conventions, to work for the faithful application of international humanitarian law applicable in armed conflicts and to take cognizance of any complaints based on alleged breaches of that law" and "to endeavour at all times - as a neutral institution whose humanitarian work is carried out particularly in time of international and other armed conflicts or internal strife - to ensure the protection of and assistance to military and civilian victims of such events and of their direct results" (Pfanner 2009, p. 290). As a general guardian of IHL, the ICRC has played an important role in enforcing IHL.

\section{Enforcement Through the United Nations System}

The main UN organs play an important role in the enforcement of IHL (Office of the High Commissioner on Human Rights 2011, p. 92-116). Other relevant UN entities include the Offices of the United Nations High Commissioner for Refugees (UNHCR) and of the United Nations High Commissioner for Human Rights (OHCHR), as well as UN agencies such as the World Food Programme (WFP), the United Nations Development Programme (UNDP), and the United Nations Children's Fund (UNICEF), which often deal with, and provide assistance to, persons affected by armed conflict, including victims of IHL violations (Melzer 2016, p. 276). This section analyzes the role of the Security Council (UNSC), the General Assembly (UNGA), and the International Court of Justice (ICJ). The Security Council has primary responsibility under the UN Charter to maintain and 
restore international peace and security, hence its inherent role with regard to the enforcement of IHL. Under Chapter VII of the UN Charter, the UNSC is entrusted with powers to indicate measures to respond to threats to and breaches of the peace through a range of measures, from those that do not involve the use of force (Article 41) to military action (Article 42). The General Assembly plays an important normative and enforcement role, including through two of its subsidiary organs, namely, the International Law Commission and the Human Rights Council. The ICJ has contributed to the enforcement of IHL through its advisory and contentious jurisdiction, as well as through provisional measures indicated in situations of armed conflict (Zyberi 2008; Zyberi 2010, p. 571-584). ICJ's decisions are very important in laying down standards of conduct under the law of international responsibility that eventually are conducive to better compliance with IHL.

\section{Enforcement Through the Security Council}

The UNSC is quite important in enforcing IHL, given its authority under Chapter VII of the UN Charter, to respond to threats to and breaches of the peace (Repertoire of the Practice of the Security Council ; Lowe et al. 2010). Under Article 41, the UNSC can undertake different measures not involving the use of force, whereas under Article 42 it can authorize military action (Resolutions 1970 (2011) and 1973 (2011) on the situation in Libya). The activity of the UNSC has been important for the enforcement of IHL, through mandating international peacekeeping operations; indicating sanctions, including travel bans, freezing of assets, and arms embargoes; establishing accountability and inquiry mechanisms; and emphasizing the protection of civilians, children, and women. In the framework of peacekeeping missions, the UNSC has established the doctrine of protection of civilians (POC) (S/RES/1265/1999, para. 4), which obliges peacekeepers to protect civilians from serious violations of human rights and humanitarian law (S/RES/1674/2006 on the protection of civilians in armed conflict; S/RES/1325/2000 on women, peace, and security; S/RES/1612/2005 on children and armed conflict).

The contribution of the UNSC to the enforcement of IHL involves both normative and operational aspects. In terms of normative aspects, it is important to highlight UNSC's attention toward the protection of women, children, and the doctrine of protection of civilians (Foley 2017). In terms of operational aspects, it is important to highlight mandating peacekeeping missions under Chapter VII of the UN Charter to use force to protect civilians from serious violations of human rights and humanitarian law, the authorization of the use of force to prevent serious violations of human rights and humanitarian law which threaten international peace and security in the case of Libya in 2011, and the establishment of mechanisms to ensure individual criminal accountability or to investigate serious violations. The Security Council has also condemned serious violations of humanitarian law in different armed conflicts and has called for accountability, including for non-State armed groups. The UNSC enforces IHL through its peacekeeping missions in different parts of the world (Koops et al. 2015; Larsen 2012; Genser and Stagno Ugarte 2014). According to the UN Department of Peacekeeping Operations (DPKO), there are about 110,000 peacekeepers in 14 missions (2018). An important part of the mandate of these missions is the use of force for the protection of civilians (Willmot and Sheeran 2013, p. 517-538). The lack of appreciation of the inherent normative basis for UN peacekeepers to protect civilians irrespective of an express mandate has resulted in the failure to recognize that UN peacekeepers will always have the authority to intervene in order to protect civilians under imminent threat of violence where the host State cannot act (Willmot and Sheeran 2013 , p. 537). A recent UN report has shown that although an inherent part of their mandate, peacekeepers have hesitated to use force to protect civilians (Howard and Dayal 2018, p. 71-103; 
Findlay 2002). At the same time, it must be noted that the UN blue helmet does not offer the expected protection from acts of violence, as peacekeepers have been increasingly targeted in recent years. The UNSC has powers that allow it to pursue a degree of individual accountability for serious violations of IHL. Thus, in 1993 and 1994, respectively, acting under Chapter VII of the UN Charter, the UNSC established the ad hoc tribunals for the former Yugoslavia and for Rwanda, in order to investigate and prosecute serious violations of IHL (S/RES/808/1993 and 827/1993;

S/RES/955/1994). The authority of the UNSC under Article 13(b) of the ICC Statute to refer to the International Criminal Court (ICC) situations where serious violations of IHL are being committed is quite important. So far, there have been two Security Council referrals, namely, Sudan (Darfur) in 2005 and Libya in 2011. Regrettably, the UNSC does not seem diligent enough in supporting the work of the ICC in investigating those crimes, as well as in ensuring that those persons charged with war crimes are brought before the ICC. Moreover, although the war in Syria has been raging for several years, the UNSC has been unable to refer the situation to the ICC due to the use of veto power by a permanent member.

As Roscini has noted, the privileged position of the Security Council, which has exclusive competence to take coercive measures involving the use of armed force and whose decisions are binding on all UN Member States, makes it potentially a formidable instrument against serious violations of IHL, which can at least partly remedy the lack of enforcing mechanisms in the treaties on the laws of war, where compliance is mainly based on the goodwill of the States parties (Roscini 2010 , p. 358). The selectivity of the UNSC, however, means that at times this international body can only play a limited role with regard to IHL enforcement.

\section{Enforcement Through the General Assembly}

The contribution of the General Assembly to the enforcement of IHL has both a normative, as well as an operational aspect, based, respectively, on Articles 10, 11, 12, 13, and 15 of the UN Charter, as well as the "Uniting for Peace" Resolution (A/RES/377(V) 1950). The normative aspect is carried out through resolutions adopted by the UNGA itself or through the work of its subsidiary bodies, especially the International Law Commission and the Human Rights Council. Starting with the 1968 Proclamation of Teheran, the UNGA has reminded parties to an armed conflict of their IHL obligations, issuing several resolutions on "Respect for Human Rights in Armed Conflict" (A/RES/2444(XXIII) 1968). An important example of normative resolutions adopted by the UNGA is the "United Nations Basic Principles and Guidelines on the Right to a Remedy and Reparation for Victims of Gross Violations of International Human Rights Law and Serious Violations of International Humanitarian Law" (A/RES/60/147 2005, especially paras. 15-23). More recently, in 2005, the UNGA has adopted the responsibility to protect doctrine (RtoP) which requires States to protect their populations from mass atrocity crimes, including war crimes (A/RES/60/1 2005, paras. 138-140). This doctrine is based on the primary responsibility of States to protect their populations from mass atrocity crimes, including war crimes, and a subsidiary responsibility on the part of the organized international community to assist States in this duty (Ryngaert and Cuyckens 2013, p. 109129). The three pillars of the RtoP doctrine are Pillar one, the protection responsibilities of the State; Pillar two, International assistance and capacity-building; and Pillar three, timely and decisive response.

The normative contribution of the General Assembly comes also through the work of its subsidiary body, the International Law Commission, mandated with the codification and progressive development of international law. The ILC has worked on several issues relevant to the enforcement 
of IHL, including "Formulation of the Nürnberg Principles," "Draft code of offences against the peace and security of mankind (Part I)," "Draft code of crimes against the peace and security of mankind (Part II) - including the draft statute for an international criminal court," "Effects of armed conflicts on treaties," "Obligation to extradite or prosecute ( aut dedere, aut judicare)," "Articles on responsibility of States for internationally wrongful acts," "Articles on the responsibility of international organizations for internationally wrongful acts," "Immunity of State officials from foreign criminal jurisdiction," "Peremptory norms of general international law ( Jus cogens)," and "Protection of the environment in relation to armed conflicts."

The operational aspect of the mandate of the UNGA is carried out mainly through its subsidiary organ, the Human Rights Council, an intergovernmental body within the United Nations system responsible for strengthening the promotion and protection of human rights and for addressing situations of human rights violations and making recommendations on them (Zhu 2014, p. 186-212). As mentioned above, another possibility is available through the UNGA's 1950 "Uniting for Peace" Resolution. The work of the Human Rights Council includes both the Universal Periodic Review (UPR), as well as the work of the special procedures, through the various Special Rapporteurs, expert groups, and agencies established or mandated within the UN framework to express their concerns, views, and recommendations with regard to IHL violations. Some of the relevant thematic Special Rapporteurs include the Special Rapporteur on extrajudicial, summary, or arbitrary executions; the Special Rapporteur on the promotion and protection of human rights and fundamental freedoms while countering terrorism; Special Rapporteur on torture and other cruel, inhuman, or degrading treatment or punishment; and the Special Rapporteur on the promotion of truth, justice, reparation, and guarantees of non-recurrence. By interpreting the terms "human rights obligations and commitments" in Operative paragraph 5(e) of General Assembly Resolution 60/251 to cover IHL, the UPR Mechanism of 18 June 2007, as a part of the Institution-building of the new Council, clearly incorporated IHL into the UPR machinery, the most innovative creation of the new Council (Zhu 2014 , p. 211). Depending on the expertise of States and the efforts and attention paid to IHL, the review of compliance with IHL under the UPR mechanism could become more comprehensive, adding another opportunity to address shortcomings concerning IHL enforcement on the part of States.

\section{Enforcement Through the International Court of Justice}

The ICJ's position as one of the main organs of the UN and its principal judicial organ makes its role quite important (Gardam 2001, p. 349-365; Chetail 2003, p. 235-268; Raimondo 2007, p. 593-611; Kress $\underline{2013}$, p. 263-298). This institutional role is reflected also in requests for advisory opinions on IHL-related issues by the General Assembly. Some of the aspects of the work of the Court which are relevant to the enforcement of IHL are State responsibility for violations of IHL; reparations due to States, legal entities, and individuals; and indication of provisional measures of protection in armed conflict situations (ICJ, Application of the Convention on the Prevention and Punishment of the Crime of Genocide 1993; Armed Activities on the Territory of the Congo 2000; Application of the International Convention on the Elimination of All Forms of Racial Discrimination 2008). As Chetail has pointed out, the Court's case law as a whole has certainly helped to strengthen and clarify the normative basis of international humanitarian law by highlighting its relationships with general international law and by setting out the basic principles governing the conduct of hostilities and the protection of victims of war (Chetail 2003, p. 268). This author has pointed out the threefold function of the ICJ with regard to developing IHL, namely, (1) first and foremost, the ICJ clarifies and 
develops rules and principles of IHL through deciding cases brought before it, (2) it integrates international humanitarian law concepts and principles within the wider framework of international law, and (3) it contributes to maintaining the unity of international humanitarian law and its uniform application by international judicial bodies operating in this field (Zyberi 2008, p. 332).

Reparations for IHL violations are important (Zegveld 2003, p. 497-527; Gillard 2003, p. 529-553). In the "Armed Activities" case, the ICJ made an explicit finding in the dispositif of its judgment about a State having violated its obligations under international humanitarian law and being under obligation to make reparation for the injury caused (ICJ, Armed Activities on the Territory of the Congo 2005, para. 345(3) and (5)). In the Wall Advisory Opinion, the ICJ found that Israel was under an obligation to make reparation for the damage caused to all the natural or legal persons affected by the construction of the wall in the occupied Palestinian territory (ICJ, Legal Consequences of the Construction of a Wall in the Occupied Palestinian Territory 2004, para. 152). The contribution of the ICJ to the enforcement of IHL is relevant in terms of the law of international responsibility, as well as concerning the awarding of reparations for serious violations of IHL.

\section{Enforcement of IHL Through International Criminal Law Mechanisms}

The enforcement of IHL is furthered by pursuing individual criminal responsibility for serious violations of IHL through international criminal courts and tribunals (Pejić 2002, p. 13-33; Darcy and Powderly 2010). Some of the most prominent courts and tribunals are the ICTY, the ICTR, and the ICC. The two ad hoc tribunals established by the UNSC continued in the footsteps of the Nuremberg and the Tokyo tribunals while addressing important questions which had not been addressed before, including the existence of war crimes in NIACs. The ICTY has played an important role in enforcing IHL by indicting 161 persons for war crimes, crimes against humanity, and genocide committed in the former Yugoslavia in the 1990s (Quéguiner 2003, p. 271-311). Some of the main contributions of the ICTY include the development of the grave breaches regime and of individual criminal responsibility, including command responsibility; bridging the protection gap between IACs and NIACs; firmly establishing the prohibition of torture under international law as a jus cogens norm; finding that most norms of international humanitarian law, in particular those prohibiting war crimes, crimes against humanity, and genocide, are also peremptory norms of international law or jus cogens (Wagner 2003, p. 351-383; Williamson 2008, p. 303-317; Zyberi 2014a, p. 395-416). The ICTR has led the way by prosecuting rape as a war crime, clarifying the law on superior responsibility, as well as by further developing the law on war crimes in NIACs (van den Herik 2005). The ICC has further developed the law on modes of individual criminal liability, as well as the law on reparations for serious violations of IHL. The reach of international criminal justice is still small though, focusing mainly on those most responsible, hence necessitating the support of domestic authorities and criminal investigation and prosecution of alleged perpetrators of war crimes before domestic courts.

\section{Enforcement by Non-State Actors}

Although States are crucial for ensuring the enforcement of IHL, non-State actors (NSAs) and especially non-State armed groups (NSAGs) have become increasingly important (Zyberi 2014b, p. 53-74; Clapham 2014, p. 766-810). Most of the ongoing armed conflicts are of a non-international 
nature, which further emphasizes the role for NSAGs in enforcing IHL. By now, it is commonly accepted that IHL binds all parties to an armed conflict, including NSAGs. Clapham has suggested a number of options that can be used to address violations of IHL by NSAs, including criminal accountability, sanctions, monitoring and reporting, encouraging codes of conduct and deeds of commitment, and initiatives aimed at the underlying causes of the conflict (Clapham 2014, p. 809810). Other relevant actors for the enforcement of IHL are nongovernmental organizations (NGOs). Many international (and local) NGOs are involved in fact-finding, publication of their findings, "naming and shaming" those who violate IHL, and lobbying relevant actors to prevent and stop IHL violations. Other relevant activities by NGOs include education and awareness-raising campaigns aimed at the broader public, as well as engagement with NSAGs in order to train or to encourage them to comply with IHL.

\section{Concluding Remarks}

War crimes are serious violations of IHL that can trigger individual criminal responsibility, State responsibility, or the responsibility of international organizations. The resurgence of NIACs and the clashes of State armed forces with NSAGs that control large parts of territory, or operate cross-border, have contributed to an increase in the number of war crimes and other violations of IHL affecting large parts of the population. While the grave breaches system only applies in IACs, customary IHL and the practice of international courts and tribunals has largely bridged the protection gap between IACs and NIACs. Over the last 150 years, different mechanisms have been established and entrusted with the enforcement of IHL at the three levels, namely, domestic, regional, and international levels. These mechanisms can have a judicial or a nonjudicial nature. The IHL enforcement system is based on the foundational obligation of States to respect and ensure respect for IHL under common Article 1 to the 1949 Geneva Conventions. The measures that States can take to enforce IHL are of a preventive, punitive, and supervisory or monitoring nature. Besides enforcement at the domestic level through domestic courts, or other relevant mechanisms, the regional human rights system is also important in ensuring respect for IHL. Although IHL per se does not fall under the purview of their jurisdiction, the regional human rights systems through the courts or commissions have managed to enforce IHL and develop relevant standards of conduct for States and other parties to armed conflicts. Some treaty-based enforcement mechanisms such as Protecting Powers, ad hoc inquiry commissions and the International Fact-Finding Comisssion have barely been used, whereas other enforcement mechanisms focusing on individual criminal responsibility such as international criminal courts and tribunals have taken on important functions in terms of ensuring accountability, reparations, and reconciliation. As Green has pointed out with regard to the future, the jurisprudence of both the tribunals for the former Yugoslavia and Rwanda might serve as a deterrent against breaches of humanitarian law, although it is more likely that what will happen is that similar ad hoc tribunals or the International Criminal Court will be called upon to enforce the law by way of post facto process and punishment (Green 2003, p. 130). The work of international criminal justice mechanisms needs to be supported and further expanded through a functioning domestic criminal justice system. The UN main organs play an important role in enforcing IHL, although their work is occasionally permeated by selectivity and power-politics calculations, as well as jurisdictional and other practical limitations. This situation has caused serious mass violations committed in armed conflicts in different parts of the world to go unstopped or unpunished. While the enforcement of IHL remains a challenge, the combination of the work of existing IHL mechanisms with those established 
with a primary function of enforcing human rights has improved the chances of having serious violations of IHL adjudicated or otherwise raised and considered at different levels and forums.

\section{References}

ACmHPR (2000) Commission Nationale des Droits de 1'Homme et des Libertés v. Chad, AHRLR 66

ACmHPR (2003) Democratic Republic of Congo v. Burundi, Rwanda and Uganda, AHRLR 19

ACmHPR (2007a) Amnesty International and others v. Sudan, AHRLR 297

ACmHPR (2007b) Article 19 v. Eritrea, AHRLR 73

ACmHPR (2009) Sudan Human Rights Organisation \& Centre on Housing Rights and Evictions (COHRE) v. Sudan, AHRLR 153

ACtHR (2011) African Commission on Human and Peoples' Rights v. Great Socialist People's Libyan Arab Jamahiriya

Additional Protocol (I) to the Geneva Conventions 1977

Additional Protocol (II) to the Geneva Conventions 1977

Azzarello C and Niederhauser M (2018) The independent humanitarian fact-finding commission: has the 'sleeping beauty' awoken?, 9 January 2018. Available at http://blogs.icrc.org/law-and-policy/2018/ 01/09/the-independent-humanitarian-fact-finding-commission-has-the-sleeping-beauty-awoken.

Accessed 27 Mar 2018

Blank LR (2011) Understanding when and how domestic courts apply IHL. Case Western Reserve Journal of International Law 44:205-224

Boisson de Chazournes L, Condorelli L (2000) Common article 1 of the Geneva conventions revisited: protecting collective interests. International Review of the Red Cross 82(837):67-87 
Bonafè B (2009) The relationship between state and individual responsibility for international crimes.

Brill, Leiden

CrossRef

Buis EJ (2008) The implementation of international humanitarian law by human rights courts: the example of the inter-American human rights system. In: Arnold R, Quénivet N (eds) International humanitarian law and human rights law: towards a new merger in international law. Martinus Nijhoff Publishers, Leiden, pp 269-293

Cerna C (2011) The history of the inter-American system's jurisprudence as regards situations of armed conflict. Journal of International Humanitarian Legal Studies 2(1):3-52

CrossRef

Chetail V (2003) The contribution of the international court of justice to international humanitarian law. International Review of the Red Cross 85(850):235-268

CrossRef

Clapham A (2014) Focusing on armed non-state actors. In: Clapham A, Gaeta P (eds) The Oxford handbook of international law in armed conflict. Oxford University Press, Oxford, pp 766-810 CrossRef

Crawford E, Pert A (2015) International humanitarian law. Cambridge University Press, Cambridge

Crawford J, Pellet A, Olleson S (eds) (2010) The law of international responsibility. Oxford University Press, Oxford

Darcy S (2014) Judges, law and war: the judicial development of international humanitarian law. Cambridge University Press, Cambridge

CrossRef

Darcy S, Powderly J (eds) (2010) Judicial creativity at the international criminal tribunals. Oxford University Press, Oxford

de Wet E, Kleffner J (eds) (2014) Convergence and conflicts of human rights and international humanitarian law in military operations. Pretoria University Law Press, Pretoria 
Dörmann K, Serralvo J (2014) Common article 1 to the Geneva conventions and the obligation to prevent international humanitarian law violations. International Review of the Red Cross 96(895/896):707-736

CrossRef

ECtHR (1995) McCann and others v. the United Kingdom (Application no. 18984/91)

ECtHR (1996) Aksoy v. Turkey (Application no. 37546/08)

ECtHR (2001) Cyprus v. Turkey (Application no. 25781/94)

ECtHR (2005) Öcalan v. Turkey (Application no. 46221/99)

ECtHR (2009) A. and others v. the United Kingdom (Application no. 3455/05)

ECtHR (2012a) El-Masri v. "The former Yugoslav Republic of Macedonia" (Application no. 39630/09)

ECtHR (2012b) Marguš v. Croatia (Application no. 4455/10)

ECtHR (2013) Stichting mothers of Srebrenica and others v. the Netherlands (Application no. $65542 / 12)$

ECtHR (2014a) Al Nashiri v. Poland (Application no. 28761/11)

ECtHR (2014b) Husayn (Abu Zubaydah) v. Poland (Application no. 7511/13)

El Zeidy M (2008) The principle of complementarity in international criminal law: origin, development and practice. Brill, Leiden

CrossRef

Findlay T (2002) The use of force in UN peace operations. Oxford University Press, Oxford 
Focarelli C (2010) Common article 1 of the 1949 Geneva conventions: a soap bubble? EJIL

21(1):125-171

CrossRef

Foley C (2017) UN peacekeeping operations and the protection of civilians: saving succeeding generations. Cambridge University Press, Cambridge

CrossRef

Gardam J (2001) The contribution of the international court of justice to international humanitarian law. Leiden Journal of International Law 14:349-365

Geneva Convention (I) on wounded and sick in armed forces in the field 1949

Geneva Convention (II) on wounded, sick and shipwrecked of armed forces at sea 1949

Geneva Convention (III) on prisoners of war 1949

Geneva Convention (IV) on civilians 1949

Genser J, Stagno Ugarte B (eds) (2014) The United Nations Security Council in the age of human rights. Cambridge University Press, Cambridge

Gill T (2013) Chivalry: a principle of the law of armed conflict? In: Matthee M, Toebes B, Brus M (eds) Armed conflict and international law: in search of the human face - liber Amicorum in memory of Avril McDonald. Springer, Heidelberg, pp 33-51

Gillard E-C (2003) Reparation for violations of international humanitarian law. International Review of the Red Cross 85(851):529-553

Gioia A (2011) The role of the European court of human rights in monitoring compliance with humanitarian law in armed conflict. In: Ben-Naftali O (ed) International humanitarian law and international human rights law. Oxford University Press, Oxford, pp 201-249

CrossRef 
Green LC (2003) Enforcement of international humanitarian law and threats to National Sovereignty. Journal of Conflict and Security Law 8(1):101-131

CrossRef

Hartridge S (2014) The European court of human Right's engagement with international humanitarian law. In: Jinks D, Maogoto JN, Solomon S (eds) Applying international humanitarian law in judicial and quasi-judicial bodies. Springer, Heidelberg, pp 257-287

Henckaerts J-M, Doswald-Beck L (eds) (2005) Customary international humanitarian law: volume I, rules; volume II, practice: part 1 and part 2. Cambridge University Press, Cambridge

IACtHR (1987a) Habeas Corpus in emergency situations (Arts. 27 (2), 25 (I) and 7 (6) American Convention on Human Rights) (advisory opinion) Ser A No 8 (30 Jan 1987)

IACtHR (1987b) Judicial Guarantees in States of Emergency (Arts. 27(2), 25 and 8 American Convention on Human Rights) (Advisory Opinion) Ser A No 9 (6 Oct 1987)

IACtHR (2000) Bámaca-Velásquez v. Guatemala (Merits and Judgment) Ser C No 70 IACHR (25 Nov 2000)

IACtHR (2006) Case of the Pueblo Bello massacre v. Colombia (Merits, Reparations and Costs) Ser C No 140 IACHR (31 Jan 2006)

ICJ (1986) Military and Paramilitary Activities in and against Nicaragua (Nicaragua v. United States of America), Merits, ICJ Reports 1986, p. 14

ICJ (1993) Application of the Convention on the Prevention and Punishment of the Crime of Genocide (Bosnia and Herzegovina v. Serbia and Montenegro), ICJ Reports 1993, p. 3

ICJ (1996) Legality of the threat or use of nuclear weapons, ICJ Reports 1996, p. 226

ICJ (2000) Armed Activities on the Territory of the Congo (Democratic Republic of the Congo v. Uganda), ICJ Reports 2000, p. 111 
ICJ (2002) Arrest Warrant of 11 April 2000 (Democratic Republic of the Congo v. Belgium), ICJ Reports 2002, p. 3

ICJ (2004) Legal consequences of the construction of a wall in the occupied Palestinian territory, advisory opinion, ICJ Reports 2004, p. 136

ICJ (2005) Armed activities on the territory of the Congo (Democratic Republic of the Congo v. Uganda, ICJ Reports 2005, p. 168

ICJ (2008) Application of the International Convention on the Elimination of All Forms of Racial Discrimination (Georgia v. Russian Federation), ICJ Reports 2008, p. 353

ICRC (2015) International humanitarian law and the challenges of contemporary armed conflicts: document prepared by the international committee of the red cross for the 32nd international conference of the red cross and red crescent, Geneva, Switzerland, 8-10 December 2015. International Review of the Red Cross 900:1427-1502

ICRC Database on National Implementation. https://ihl-databases.icrc.org/ihl-nat

ICTR $(2008,2011)$ Bagosora et al. (Military I) (ICTR-98-41)

ICTR $(1998,2000)$ Jean Kambanda (ICTR-97-23)

ICTR (1998, 2001) Jean Paul Akayesu (ICTR-96-4)

ICTY (2016) Radovan Karadžić (IT-95-5/18)

ICTY (2017) Ratko Mladić (IT-09-92)

ICTY (1995) Duško Tadić (IT-94-1-AR72)

ICTY $(2001,2002)$ Kunarac et al. (IT-96-23 \& IT-96-23/1) 
ICTY (2013, 2017) Prlić et al. (IT-04-74)

ICTY $(2009,2014)$ Šainović et al. (IT-05-87)

ICTY $(2005,2007)$ Limaj et al. (IT-03-66)

Inazumi M (2005) Universal jurisdiction in modern international law: expansion of national jurisdiction for prosecuting serious crimes under international law. Intersentia, Cambridge

International Crimes Database, T.M.C. Asser Institute. www.internationalcrimesdatabase.org

Jørgensen N (2003) The responsibility of states for international crimes. Oxford University Press, Oxford

Kalshoven F (2007) Implementation and enforcement of international humanitarian law. In: Kalshoven F (ed) Reflections on the law of war: collected essays. Brill, Leiden, pp 593-620 CrossRef

Kleffner J (2008) Complementarity in the Rome statute and national criminal jurisdictions. Oxford University Press, Oxford CrossRef

Koops J, MacQueen N, Tardy T, Williams PD (eds) (2015) The Oxford handbook of United Nations peacekeeping operations. Oxford University Press, Oxford

Kress C (2013) The international court of justice and the law of armed conflicts. In: Tams C, Sloan J (eds) The development of international law by the international court of justice. Oxford University Press, Oxford, pp 263-298

Krieger H (ed) (2015) Inducing compliance with international humanitarian law: lessons from the African Great Lakes region. Cambridge University Press, Cambridge

Kwakwa E (2004) The Cairo-Arusha principles on universal jurisdiction in respect of gross human rights offenses: an African perspective. In: Yusuf A (ed) African yearbook of international law/Annuaire Africain de Droit International, volume 10 (2002). Nijhoff, The Hague, pp 407-430 
Larsen KM (2012) The human rights treaty obligations of peacekeepers. Cambridge University Press, Cambridge

CrossRef

Lowe V, Roberts A, Welsh J, Zaum D (eds) (2010) The United Nations security council and war: the evolution of thought and practice since 1945. Oxford University Press, Oxford

Macedo S (2006) Universal jurisdiction: national courts and the prosecution of serious crimes under international law. University of Pennsylvania Press, Philadelphia

Melzer N (2016) International humanitarian law: a comprehensive introduction. ICRC, Geneva

Morjé Howard L, Dayal AK (2018) The use of force in UN peacekeeping. Int Organ 72(1):71-103 CrossRef

Nerlich V (2009) War crimes. In: Cassese A (ed) The Oxford companion to international criminal justice. Oxford University Press, Oxford, pp 566-570

Nouwen S (2013) Complementarity in the line of fire: the catalysing effect of the international criminal court in Uganda and Sudan. Cambridge University Press, Cambridge CrossRef

Oberleitner G (2015) Human rights in armed conflict. Cambridge University Press, Cambridge CrossRef

Oellers-Frahm K (2014) A regional perspective on the convergence and conflicts of human rights and international humanitarian law in military operations: the European court of human rights. In: de Wet E, Kleffner J (eds) Convergence and conflicts of human rights and international humanitarian law in military operations. Pretoria University Law Press, Pretoria, pp 333-364

Office of the High Commissioner on Human Rights (2011) International legal protection of human rights in armed conflict. United Nations, Geneva 
Orakhelashvili A (ed) (2015) Research handbook on jurisdiction and immunities in international law. Edward Elgar Publishing, London

Pejić J (2002) Accountability for international crimes: from conjecture to reality. International Review of the Red Cross 84(845):13-33

CrossRef

Pfanner T (2009) Various mechanisms and approaches for implementing international humanitarian law and protecting and assisting war victims. International Review of the Red Cross 91(874):279-328 CrossRef

Princeton Project on Universal Jurisdiction (2001) The Princeton principles on universal jurisdiction. Program in law and public affairs. Princeton University, Princeton

Quéguiner J-F (2003) Dix ans après la création du Tribunal penal international pour l'exYougoslavie: évaluation de l'apport de sa jurisprudence au droit international humanitaire. International Review of the Red Cross 85(850):271-311

CrossRef

Raimondo F (2007) The international court of justice as a guardian of the unity of humanitarian law. Leiden Journal of International Law 20:593-611

CrossRef

Roscini M (2010) The United Nations security council and the enforcement of international humanitarian law. Israel Law Review 43(2):330-359

CrossRef

Ryngaert C, Cuyckens H (2013) The general assembly. In: Zyberi G (ed) An institutional approach to the responsibility to protect. Cambridge University Press, Cambridge, pp 109-129

CrossRef

Sassòli M (2002) State responsibility for violations of international humanitarian law. International Review of the Red Cross 84(846):401-434

CrossRef

Sassòli M (2007) The implementation of international humanitarian law: current and inherent challenges. Yearbook of International Humanitarian Law 10:45-73 
CrossRef

Schabas WA (2001) Enforcing international humanitarian law: catching the accomplices.

International Review of the Red Cross 83:439-459

Schmitt M, von Heinegg WH (eds) (2012) The implementation and enforcement of international humanitarian law. Ashgate, Aldershot

Seibert-Fohr A (2009) Prosecuting serious human rights violations. Oxford University Press, Oxford CrossRef

Shelton D (2014) Humanitarian law in the inter-American human rights system. In: de Wet E, Kleffner J (eds) Convergence and conflicts of human rights and international humanitarian law in military operations. Pretoria University Law Press, Pretoria, pp 365-394

Stahn K, El Zeidy M (eds) (2011) The international criminal court and complementarity: from theory to practice. Cambridge University Press, Cambridge

Tabak S (2016) Ambivalent enforcement: international humanitarian law at human rights tribunals. Michigan Journal of International Law 37:661-715

UK Ministry of Defence (2004) The manual of the law of armed conflict. Oxford University Press, Oxford

US Supreme Court (2006) Hamdan v. Rumsfeld, 548 U.S. 557

US Supreme Court (2008) Boumediene v. Bush, 553 U.S. 723

van Alebeek R (2008) The immunity of states and their officials in international criminal law and international human rights law. Oxford University Press, Oxford CrossRef

van den Herik L (2005) The contribution of the Rwanda tribunal to the development of international law. Martinus Nijhoff Publishers, Leiden/Boston 
van Sliedregt E (2012) Individual criminal responsibility in international law. Oxford University Press, Oxford

Viljoen F (2014) The relationship between international human rights and humanitarian law in the African human rights system: an institutional approach. In: de Wet E, Kleffner J (eds) Convergence and conflicts of human rights and international humanitarian law in military operations. Pretoria University Law Press, Pretoria, pp 303-332

Vité S (2009) Typology of armed conflicts in international humanitarian law: legal concepts and actual situations. International Review of the Red Cross 91(873):69-94

CrossRef

Vöneky S (2013) Implementation and enforcement of international humanitarian law. In: Fleck D (ed) The handbook of international humanitarian law, 3rd edn. Oxford University Press, Oxford, pp 647700

Wagner N (2003) The development of the grave breaches regime and of individual criminal responsibility by the international criminal tribunal for the former Yugoslavia. International Review of the Red Cross 85(850):351-383

CrossRef

Weill S (2014a) The role of national courts in applying international humanitarian law. Oxford University Press, Oxford

CrossRef

Weill S (2014b) Building respect for IHL through national courts. International Review of the Red Cross 96(895/896):859-879

CrossRef

Williamson JA (2008) Some considerations on command responsibility and criminal liability. International Review of the Red Cross 90(870):303-317

CrossRef

Willmot H, Sheeran S (2013) The protection of civilians mandate in UN peacekeeping operations: reconciling protection concepts and practices. International Review of the Red Cross 95(891/892):517-538 
CrossRef

Zegveld L (2003) Remedies for victims of violations of international humanitarian law. International Review of the Red Cross 85(851):497-527

CrossRef

Zhu L (2014) International humanitarian law in the universal periodic review of the UN human rights council: an empirical survey. Journal of International Humanitarian Legal Studies 5:186-212 CrossRef

Zyberi G (2008) The humanitarian face of the international court of justice: its contribution to interpreting and developing international human rights and humanitarian law rules and principles. Intersentia, Cambridge

Zyberi G (2010) Provisional measures of the international court of justice in armed conflict situations. Leiden Journal of International Law 23:571-584

CrossRef

Zyberi G (2014a) The jurisprudence of the international court of justice and international criminal courts and tribunals. In: de Wet E, Kleffner J (eds) Convergence and conflicts of human rights and international humanitarian law in military operations. Pretoria University Law Press, Pretoria, pp $395-416$

Zyberi G (2014b) The role of non-state actors in implementing the responsibility to protect. In: Ryngaert C, Noortmann M (eds) Human security and international law: the challenge of non-state actors. Intersentia, Cambridge, pp 53-74 